\title{
Encapsulated Curcuma aeruginosa: Inhibition Method of Bitter Receptor Cells from The Perspective of Wall Formation
}

\author{
Monang Sihombing ${ }^{1}$ and Victoria Kristina Ananingsih ${ }^{2}$ \\ ${ }^{1}$ Department of Food Technology, Faculty of Medicine and Health Sciences, Universitas Kristen Satya \\ Wacana, Salatiga, Indonesia \\ ${ }^{2}$ Department of Food Technology, Faculty of Agriculture, Soegijapranata Catholic University, Semarang, \\ Indonesia
}

\begin{abstract}
Curcuma aeruginosa is one of the herbs with health benefits and has been used in traditional medicine, has the characteristic bitter taste, so that limited use was. The formation of walls in the active component coating process can minimize direct contact of bitter receptor cells in the oral peripherals so the perception of bitterness can be reduced. This study used a variation of the WPI concentration as the coating wall materials $10 \%$, $15 \%$ and $20 \%$. Formation of coating walls was analyzed using SEM later in the sensory test for effectiveness decreased level of bitterness. The addition of $10 \%$ WPI results in the best wall formation was in Curcuma aeruginosa, which could decrease perception of significant bitterness. In contrast to the addition of WPI $15 \%$ and $20 \%$ were found in an oval shape, craters and ruptures form on coating wall, reducing the protection of the core component and contact with bitter receptor cells in the oral peripheral resulting in bitters taste perception increasing.
\end{abstract}

Keywords: bitter receptor cell, Curcuma aeruginosa, encapsulation-spray drying, SEM, WPI

Received 03 June 2018 | Revised 07 August 2018 | Accepted 20 August 2018

\section{Introduction}

Curcuma aeruginosa is one of the herbs of the family Zingerberaceae, which are found in Myanmar, Cambodia, Vietnam, Malaysia, Thailand and Indonesia [1]. Curcuma aeruginosa contains compounds with pharmacological activity, so it is good for health [2], [3] but has a bitter perception and less acceptable sensory characteristics [4], [5]. Therefore, Curcuma aeruginosa more widely used as a seasoning in culinary and health treatment [6], [7].

There are three approaches to overcome bitterness: oral peripheral physiological receptor interactions with cells (eg, via receptor inhibitors), physico-chemical interactions in a food or beverage matrix and the central cognitive mixture suppression [8]. The method for blocking the

*Corresponding author at: Department of Food Technology, Faculty of Medicine and Health Sciences, Universitas Kristen Satya Wacana, Jl. Diponegoro No. 52-60, Salatiga, Indonesia

E-mail address: monang.sihombing@staff.uksw.edu 
interaction of oral peripheral physiological sensor cells by providing a physical barrier, considered as the most effective in reducing the perception of a bitter taste. Encapsulation is a technology that has long been known to provide a physical barrier [9] while providing more beneficial characteristics for the product [10] and has been used method for reducing the bitterness [11], [12].

Limitation use of Curcuma aeruginosa as seasoning and medicine were because of the bitter taste perception of active compound contained therein, which is the basis of this research. This study used spray drying as a proven encapsulation method in the drug industry to mask the bitter taste [13], [14]. The coating material that was used as a physical barrier was whey protein isolate (WPI) which was capable to forming the microcapsules at a medium temperature heating without the addition of chemicals as well as contributing to the organoleptic characteristics of the product [15], [16]. The purpose of this study was to see the effectiveness of the formation of a physical barrier wall to protect the Curcuma aeruginosa active compound from contact with the cell receptor through morphological analysis powder particles.

\section{Materials and Methods}

\subsection{Materials}

The main raw material was obtained from the Curcuma aeruginosa Salatiga wholesale market. The coating material used whey protein isolate (ISO Cool ${ }^{\circledR}$ ) with a protein content of $85-90 \%$, which was obtained from a supplement store in Jogjakarta. Distilled water was obtained from the chemical analytical Laboratory of Soegijapranata Catholic University, Semarang. Standar sample of non-WPI was made on chemical analytical Laboratory of Soegijapranata Catholic University, Semarang

\subsection{Methods}

\section{a. Preparation filtrate}

Curcuma aeruginosa were washed unpeeled then slices (Robot Coupe GL 50) and soaked in distilled water at a ratio of 1: 3 of Curcuma aeruginosa. The solution in less than 48 hours rests and then filtered to the remaining solids. The filtrate was collected in a light-tight container and stored in a freezer.

\section{b. Encapsulation Curcuma aeruginosa}

The filtrate was added WPI each with a variation of concentration $10 \%, 15 \%$ and $20 \%$ of Curcuma aeruginosa filtrate weight $(\mathrm{w} / \mathrm{w})$. Machine spray dryer using a temperature of $85^{\circ} \mathrm{C} \pm$ $5^{\circ} \mathrm{C}$ input and output temperature of $70 \mathrm{C} \pm 5^{\circ} \mathrm{C}$. Wind pressure of 4-5 bar, with a spraying rate of $10-11 \mathrm{ml} / \mathrm{min}$. Nozzle atomizer at the smallest position (maximum). Standard powder (without the addition of WPI) is made by drying the filtrate Curcuma aeruginosa with Freeze 
drying method for approximately 24 hours, then crushed and made homogenization of the particle size using an 80 mesh.

\section{c. Powders particle morphology analysis}

The encapsulation wall formation analysis as a physical barrier as well as a protective compound of active Curcuma aeruginosa was performed using JSM-6510 series Scanning Electron Microscopy (SEM) method, with magnification up to 3000x for each addition of WPI concentration.

\section{d. Bitterness level analysis}

The bitterness was analyzed using sensory the method. WPI - Curcuma aeruginosa powder was applied in ice cream product with the same amount of total solids all for a whole treatment. Selection of panelists was done using traceability test ranking of the standard solution then selected panelists will be used in two stages further of powder bitterness level verification test. The first stage was to test the bitterness level of all treatment WPI addition 10\%, 15\% and $20 \%$. Sample with the lowest perception of bitterness level was then compared with a standard sample of non-WPI in rating bitterness test, to see the effectiveness of a decrease in bitter taste perception after coating.

\section{Results and Discussion}

\subsection{Powders Particle Morphology}

The results in Figure 1 showed SEM particles formed for all variations concentration of WPI that was a Skin-forming type, with variations in wall coating that was perfectly round (Figure 1d), cratered (Figure 1b), oval (Figure 1a) and ruptures (Figure 1c). Formation of a different wall coating showed the difference in evaporation rate of wall material during the drying process. The coating process occurs faster than the process of evaporation from the walls of the coating will have an impact on the formation of particles with a more symmetrical wall coating covering the entire surface [17].

In addition, WPI concentration of $10 \%$, the coating process was faster than evaporation coating walls, so that the coating walls are perfectly coated. In addition $15 \%$ of WPI concentration resulted variation in wall coating formation. Most particle symmetrical on shape but many found the walls formed the crater, ruptures and started to look oval on shape. The phenomenon of the formation of craters or crack on the wall was caused by the evaporation rate at the core more quickly but being trapped by a wall formation, resulting higher pressure on the core particles than ambient pressure environment, thus forming air bubbles. The formation of bubbles creates a wall structure of the coating weaker. 


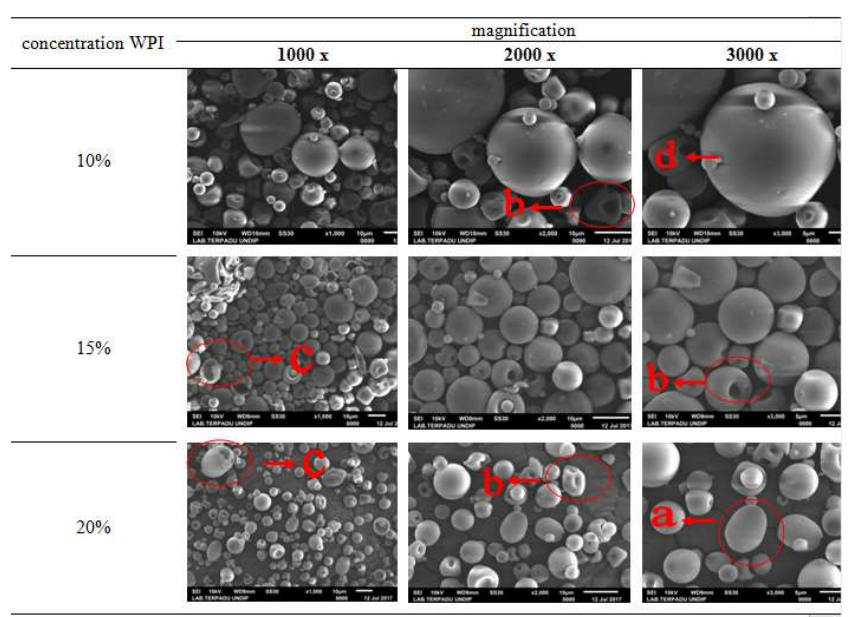

Figure 1. (a) oval wall; (B) crater wall; (C) rupture wall; (D) perfect coating wall

However, if the formation of a coating walls strong enough to withstand the pressure, then the pressure will push the wall surface coating gets in the core particle to form a crater [18] [19], The mechanism of the formation of craters and holes in the walls of the coating can be seen in Figure 2 .

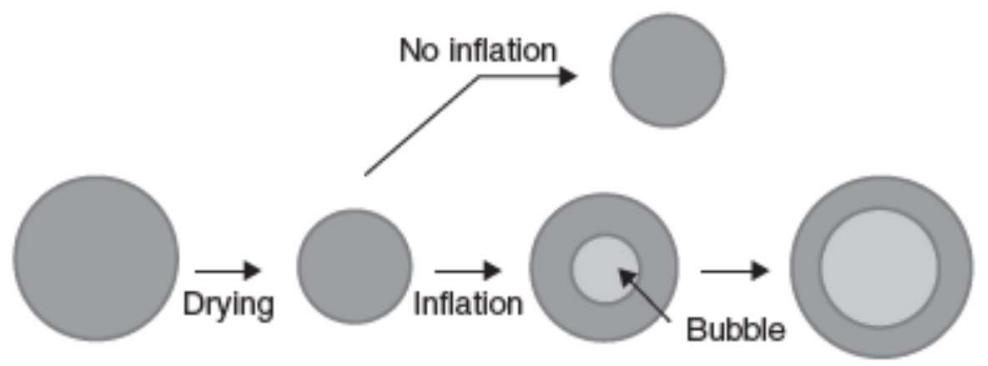

Figure 2. The Mechanism of Bubble Formation Within the Wall of The Coating [20]

The formation of particles are originated from the formation of droplets. The liquid that accepts the pressure will be increasing in length and reach a critical value, fall vertically under gravity then decomposed into a steam of droplets that occurs primarily due to the decrease in surface tension[19]. Consistency concentration in solution becomes an important factor in getting the consistency of the particle droplet size. In addition, the pressure supplied to the spray nozzle with $20 \%$ WPI did not change, resulting in the formation of oval droplets because of the ambient pressure is not enough to form droplet perfectly before formation of the wall is completed. This mechanism resulting powder particles wall forms holes, craters, fractures or ruptures wall.

\subsection{Bitterness Level}

One purpose of encapsulation is to protect the core substance of environmental conditions, as well as providing more benefits and characteristics of the product [20], [21], [22]. More 
concentration of the coating that was added, more less original characteristics of the core material [23], [24], eg bitter taste. Bitterness level resulted from sensory test shown in Table 1.

Table 1. Panelist Response in Bitterness Level Ranking Test

\begin{tabular}{cccc}
\hline \multirow{2}{*}{ Level bitter } & \multicolumn{3}{c}{ The number of respondents (people) } \\
\cline { 2 - 4 } & Ice cream 1 & Ice cream 2 & Ice cream 3 \\
\hline 1 & 1 & 10 & 24 \\
2 & 9 & 16 & 10 \\
3 & 25 & 9 & 1 \\
\hline
\end{tabular}

Information:
a. Level bitter ranking scale (1) less bitter; (2) bitter; (3) The most bitter
b. Total panelists used were 35 people untrained selection results
c. Ice cream 1: Curcuma aeruginosa - WPI 10\%; Ice cream 2: Curcuma aeruginosa - WPI 15\%; ice cream 3: Curcuma aeruginosa - WPI $20 \%$.

From the sensory test, 24 of the 35 panelists stated an ice cream Curcuma aeruginosa - WPI $20 \%$ have the most bitter taste and 25 people from a total of 35 panels stating ice cream Curcuma aeruginosa - 10\% WPI as least bitter. Based on a statistical test known that the addition concentration of WPI given a significantly different response to the level of bitterness with a significance value of $\mathrm{P}<0.05$, and the calculated value of Chi-squared 31.6 larger chi squared table with df 2 at 5,991 . The addition of $10 \%$ WPI it provides the lowest level of bitterness and an increasingly bitter as the addition of WPI concentrations as well.

Wall powder particle of WPI-Curcuma aeruginosa $15 \%$ and $20 \%$, SEM test showed the imperfections coating of the core components with the formation of craters and holes on the wall. These conditions resulted in the core component, Curcuma aeruginosa, being unprotected and exposed to the environment. As a result, the core component potentially came out when processing of ice cream and mixed together with other materials. The processing of cold ice cream helped to minimize the damage of the filtrate and then contact with the bitter sensor peripherals enhancing bitter sensory perception.

The effectiveness of the formation of the wall of the level of bitterness Curcuma aeruginosa in sensory tested by comparing the 10\% WPI powder, the most perfect wall formation among models, comparing with Curcuma aeruginosa non-WPI powder added, which is dried by freeze drying method on bitterness level rating test method that shown on Table 2.

Based on the sensory test results, the formation of the perfect wall on the addition of WPI $10 \%$ resulted in significantly decreasing bitterness level perception. At this stage, the majority of panelists who are not familiar with herbal accepted the level of bitterness. The formation of a perfect coating wall capable of protecting the core active component therein, thus not directly exposed to the bitter receptor cells in the peripheral mouth. 
Table 2. Response panelists in Bitterness level rating test

\begin{tabular}{ccc}
\hline $\begin{array}{c}\text { The level of } \\
\text { bitterness }\end{array}$ & $\begin{array}{c}\text { Without WPI } \\
\text { (Filtrate Curcuma } \\
\text { Black) }\end{array}$ & $\begin{array}{c}\text { The addition of } \\
\text { WPI 10\% }\end{array}$ \\
\hline 1 & 34 & 1 \\
2 & 0 & 0 \\
3 & 1 & 34 \\
4 & 0 & 0 \\
5 & 0 & 0 \\
\hline Information: The level of bitterness (1) Very bitter (2) Bitter; (3) A \\
little bitter; (4) Less bitter; (5) Not Bitter
\end{tabular}

\section{Conclusion and Policy Implication}

Base on the discussion and research test, the addition of 10\% WPI concentration of the Curcuma aeruginosa filtrate, resulted the best coating wall between the addition of WPI 15\% and $20 \%$, so as to effectively minimize direct contact with the core components of bitter receptor cells in the peripheral mouth. Changes in the concentration of the coating material influence on the formation of the walls of the coating, so that the pressure and temperature of the process should be adjusted to produce the desired characteristics of the coating walls.

\section{REFERENCES}

[1] S. Jose S and T. D. Thomas, "Comparative phytochemical and anti-bacterial studies of two indigenous medicinal plants Curcuma caesia Roxb. and Curcuma aeruginosa Roxb," International Journal of Green Pharmacy, vol. 8, no. 1, pp. 65-71, 2014.

[2] E. Le Berrre, C. Boucon, M. Knoop, and G. Dijksterhuis, "Reducing bitter taste through perceptual constancy created by an expectation, Food Quality and Preference, vol. 28, no. 1, pp. 370-374, 2013.

[3] E. Marlina, T. S. Tjahjandarie, and M. Tanjung, "Aktivitas antioksidan senyawa flavonoid dari Macaranga peasrsonii Merr," Jurnal Kimia Mulawarman, 13, no. 2, pp. 4-7, 2016.

[4] N. Harmanto and A. Subroto, Pilih Jamu dan Herbal Tanpa Efek Samping. Jakarta, PT .Elex Media Komputindo, 2007.

[5] D. A. Permata and K. Sayuti, "Pembuatan Minuman Serbuk Instan Dari Berbagai Bagian Tanaman Meniran (Phyllanthus Niruri)," Jurnal Teknologi Pertanian Andalas, vol. 20, pp. 44-49, 2016.

[6] G. R. Angel, B. Vimala, and B. Nambisan B, "Antioxidant and antimicrobial activity of essential oils from nine starchy curcuma species," International Journal of Current Pharmacy Research, vol. 4, no. 2, pp. 4-6, 2012.

[7] T. K. Lim, "Curcuma aeruginosa. In Edible Medicinal and Non-Medicinal Plants," Dordrecht: Springer Netherlands, p. 233-40, 2012.

[8] R. S. J. Keast, "Modification of the bitterness of caffeine," Food Quality and Preference, vol. 19, no. 5, pp. 465-472, 2008.

[9] P. De Vos, M. M. Faas, M. Spasojevic, and J. Sikkemaa, "Encapsulation for preservation of functionality and targeted delivery of bioactive food components," International Journal of Chemistry Technology Research, vol. 8, no. 11, pp. 587-598, 2015. 
[10] Y. Wang, Z. Lu, F. Lv, and X. Bie, "Study on microencapsulation of curcumin pigments by spray drying," European Food Research Technology, vol. 229, no. 3, pp. 391-396, 2009.

[11] J. P. Ley, "Masking bitter taste by Molecules," Chemosensory Perception, vol. 1, no. 1, pp. 58-77, 2008.

[12] S. Sharma and S. Lewis, "Taste masking technologies : A review," International Journal of Pharmacy and Pharmaceutical Sciences, vol. 2, no. 2, 2010.

[13] K. I. Cumming and E. M. Harris, Taste Masked Technology. United States Patent, 2000.

[14] A. M. Morella et al., Taste Masked Liquid Suspensions. United States Patent, 2001.

[15] C.V. Morr and Ha EY, "Whey protein concentrates and isolates: Processing and functional properties," Food Science and Nutrition, vol. 33, no. 6, pp. 37-41, 1993.

[16] R.A. Awad, Z. M. R. Hassan, A. F. Farrag, M. M. El-Sayed, and T. N. Soliman, "The use of whey portien isolate in microencapsulation of curcumin," International Journal of Food Nutrition Science, vol. 4, no. 3, pp. 125-131, 2015.

[17] M. Eslamian and N. Ashgriz, Spray Drying, Spray Pyrolysis and Spray Freeze Drying. Handbook of Atomization and Sprays, 2011.

[18] J. Sloth, "Formation of Enzyme Containing Particles by Spray Drying," Research Centre Department of Chemical Engineering Technical University of Denmark; 2008.

[19] C. Anandharamakrishnan, Padma, and S. Ishwarya, Spray Drying Techniques for Food Ingredient Encapsulation. Wiley-Blackwell, 2015.

[20] K. G. H. Desai and H. J. Park, "Recent developments in microencapsulation of food ingredients," Drying Technology, vol. 23, no, 7, pp. 1361-1394, 2005.

[21] Madene A, M. Jacquot, J. Scher, and S. Desobry, "Flavour encapsulation and controlled release - A review," International Journal of Food Science Technology, vol. 41, no. 1, pp. $1-21,2006$.

[22] V. Nedovic, A. Kalusevic, V. Manojlovic, S. Levic, and B. Bugarski, "An overview of encapsulation technologies for food applications," Procedia Food Science, vol. 1, pp. 1806-1815, 2011.

[23] T. Kha, "Effects of Different Drying Processes on the Physicochemical and Antioxidant Properties of Gac Fruit Powder," Master thesis, The University of Newcastle, 2010.

[24] S. N. Bhusari, K. Muzaffar, and P. Kumar, "Effect of carrier agents on physical and microstructural properties of spray dried tamarind pulp powder," Powder Technology, vol. 266, pp. 354-364, 2014. 